\title{
Corticosterone Secretion Rate in Normal and Hypertensive Subjects
}

\author{
Chikashi SASAKI \\ Department of Internal Medicine, Tohoku University School of Medicine, Sendai, Japan \\ (Director : Professor Tatsuo Torikai, M.D.)
}

The corticosterone secretion rate was studied by an isotope dilution method in 16 resting, 9 lightly working and 7 heavily working normal subjects and 6 patients with essential hypertension, 5 with renovascular hypertension and in 5 with primary aldosteronism.

No significant difference was found in the rate of corticosterone secretion among the three groups of resting normal subjects, light workers and heavy workers.

The corticosterone secretion rate in 25 normal subjects (16 resting subjects and 9 light workers) varied between $1.5 \mathrm{mg}$ and $4.3 \mathrm{mg}$ per day with a mean of $2.6 \mathrm{mg}$ per day.

No significant correlation was observed between the corticosterone secretion rate and body weight or body surface area.

ACTH stimulation induced a remarkable increase (more than tenfold) in the rate of corticosterone secretion in 2 normal subjects. A low value, $0.3 \mathrm{mg}$ per day, was obtained in a patient with panhypopituitarism due to craniopharyngioma.

The corticosterone secretion rate in 6 patients with benign essential hypertension and 5 with renovascular hypertension was observed to remain within the normal range.

In two out of five patients with primary aldosteronism due to adrenal adenoma, the secretion rate of corticosterone was significantly elevated, whereas in the other 3 it was within the normal range. Compared with the latter, those two cases with the higher corticosterone secretion revealed to have a lower serum potassium concentration and a more elevated potassium clearance measured after sodium thiosulfate loading. From this result it is suggested that corticosterone plays a role in the potassium metabolism in man.

(pp. 801 813) 


\section{Corticosterone 分泌量に関する研究}

とくに健常者並びに各種高血圧患者における分泌量について

東北大学医学部鳥飼内科教室（指導：鳥飼龍生教授）

佐々木啇

(昭和 41 年 3 月 1 日受付)

緒言

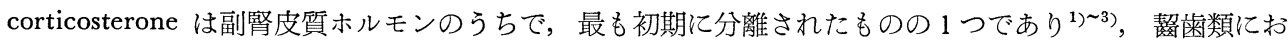
いては生命維持に不可欠な副腎皮質ホルモンは，主として corticosterone であるてとが知られている。しか しヒトにおいては， cortisolや pldosterone が生理的あるいは病的状態においてぞの椂な役割をはたすかに ついてはかなり明かにされているのに，corticosterone の作用機序については不明の点が少なくない，なぜ ならてのホルモンがヒトにおいてはたしてどの程度分泌され，また諸疾患時にどの様に変動するかというて とについては，未だ充分な検索がなされていないからである。

かかる観点から私は，まず corticosterone分泌量の測定法を吟味し，ついで健常者におけるcorticosterone 分泌量が, 諸条件下, すなわち, 安静時, 普通労働時並びに重労㗢時においてどの様な変動を示すかを検討 した，更に各種高血圧患者における分泌量についても検索し，興味ある知見を得た，以下その成績を報告す る.

\section{実 験 対 象}

\section{1. 健 常 者}

安静時対照例としては, 鳥飼内科入院中の軽症な胃腸疾患や神経疾患患者のうち, 内分泌異常, 腎機能障 害, 肝機能障害, 高血圧等のいずれをも有しない男子10例，女子 6 例，計16例を選んだ，年令別には16才か ら61才の範囲にあつた。

普通労働時対象例は, 福島県常磐炭鉱において, 坑外の執務その他の軽労働に従事していた男子 9 例で, 年令別には31才から48才の範囲にあつた.

重労働時対象例としては，同炭鉱において，高温多湿下（気温 $33^{\circ} \mathrm{C}$, 湿度 $92 \%$ ) で午後 2 時から 8 時間に わたり採炭に従事した男子 7 例を選んだ。年令別には38才から51才の範囲にあつた.

\section{2. 高血圧患者}

良性本態性高血圧患者は，最高血圧が160〜 $180 \mathrm{~mm} \mathrm{Hg}$ ，最低血圧が $90 \sim 100 \mathrm{~mm} \mathrm{Hg}$ の症例 6 例で，いず れも腎機能障害を伴わず，眼底変化も極く軽度であつた。

腎血管性高血圧症 5 例は, 腎動脈撮影, renogram, Howard's test および血中 renin 活性の測定により 本症であるてとが確められた例で，うち 3 例は手術によりてれが確認された。

原発性 aldosterone 症としては, 諸検査成績により本症と診断され，さらに手術により副篎腺腫が確認さ れた症例 5 例を対象とした。

\section{実 験 方 法}

corticosterone 分泌量の測定法は, Fig. 1 亿示した如くである.

\section{1）放射性 corticosterone の投与法}


Fig. 1. Procedure for the Determination of Corticosterone Secretion Rate

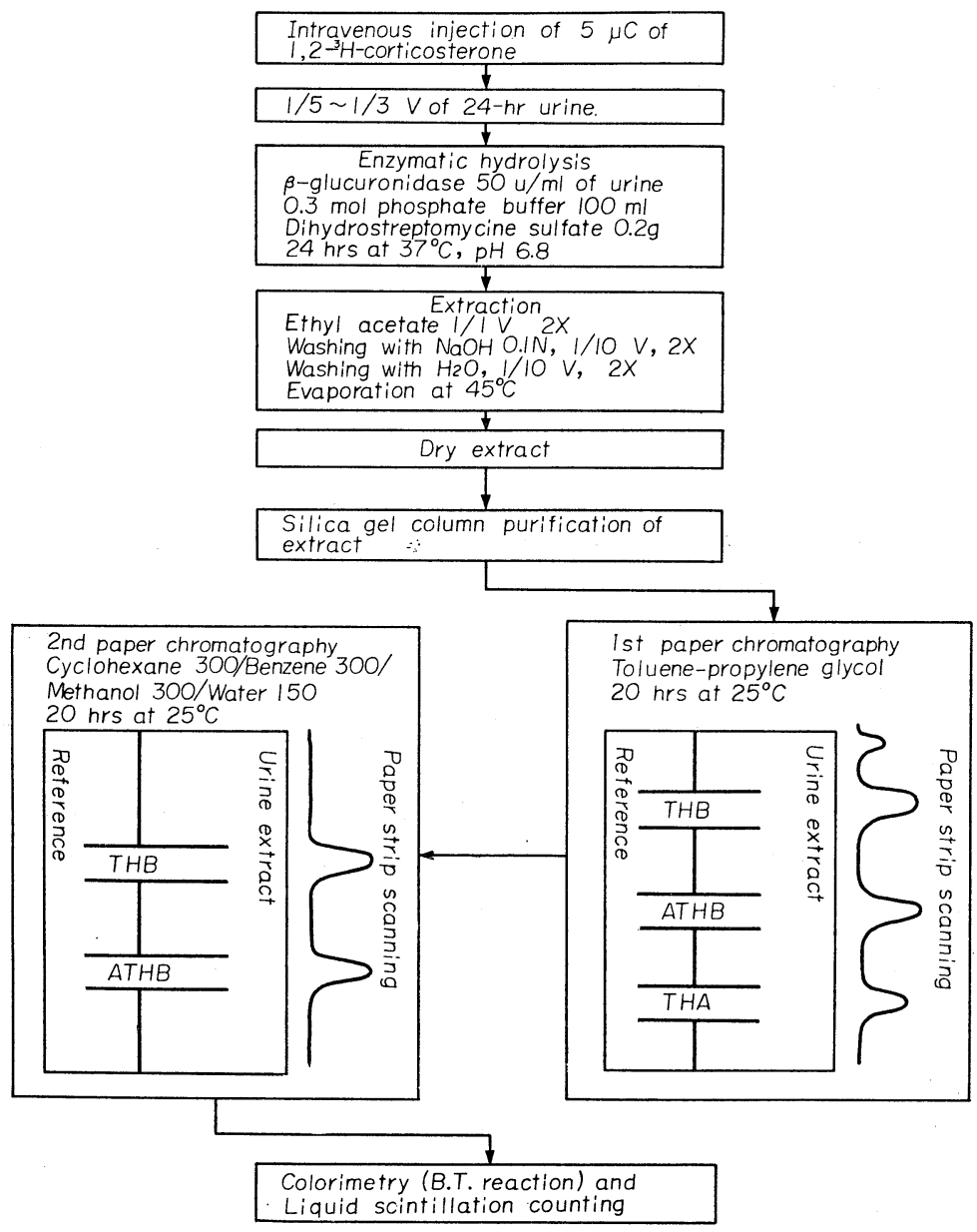

Radiochemical Centre 製 $1,2-{ }^{3} \mathrm{H}$-corticosterone の ethanol 溶液を, 1 ampoule $1 \mathrm{ml}$ 中に $5 \mu \mathrm{C}$ 含有 する様に作製した。 ての 1 ampoule を $22 \mathrm{ml}$ 生理的食塩水に溶解し, その $20 \mathrm{ml}$ を正確に経静脈的に投与 した. 残りの溶液の $1 \mathrm{ml}$ liquid scintillation counter で count し，それを20倍して isotope 投与量を 算出した.

安静時および普通労働時の健常対象例や各種高血圧患者では，いずれも朝 9 時に isotope を投与したが， 重労㗢例では労働開始直前の午後 2 時に投与した.

\section{2) 蓄尿, 加水分解および抽出方法}

標識 corticosterone の静注直後より 24 時間にわたり $4{ }^{\circ} \mathrm{C}$ 以下で正確に蓄尿し，その $1 / 5 \sim 1 / 3$ 容量の尿を 測定に供した。乙の際の尿量は，後述する比色操作において実際に比色されるステロイドが少なくとも $2 \mu \mathrm{g}$ 以上になる様に加減したわけである。

まず等容の ethyl acetate で 2 回抽出し free の steroids を除去した後, 細菌性 $\beta$ glucuronidase(Sigma 社製）を尿 $1 \mathrm{ml}$ あたり50単位添加した。更に dihydrostreptomycine sulfate $0.2 \mathrm{~g}$ 添加後, $0.3 \mathrm{~mol}$ 燐酸 buffer $100 \mathrm{ml}$ を加えてpH6.8に調整し，38ㄷ24時間 incubate した. 次いで等容の ethyl acetate で 2 回抽出し，乙れを $1 / 10$ 容量の $0.1 \mathrm{~N} \mathrm{NaOH} \mathrm{で} 2$ 回， $1 / 10$ 容量の蒸溜水で 2 回洗滌した. 洗滌液はその倍容 
Fig. 4. The Absorption Maxima of the Curve Obtained with THB

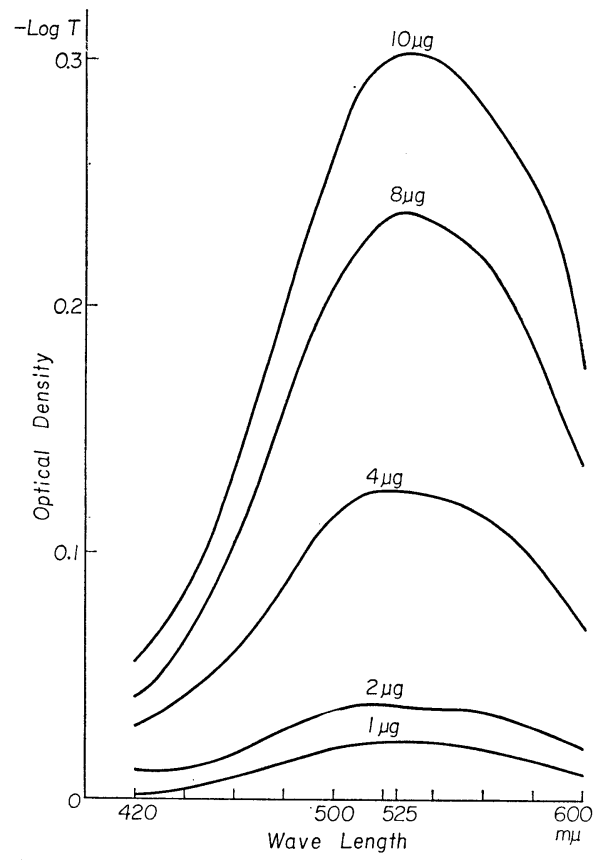

Fig. 6. Comparison of the Value of Corticosterone Secretion Rate Calculated from THB with That of ATHB

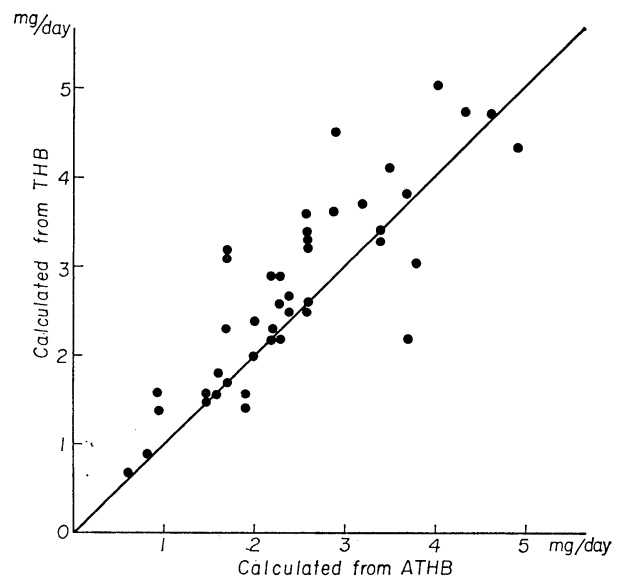

相加平均より求めた值を示すとととした (Table 1).

3）健常者における corticosterone 分泌量

安静臥床者16例, 普通学働者 9 例, 高温多湿下にお ける重労働者 7 例の corticosterone 分泌量は Fig. 7亿 示した.すなわちこれら 3 群の間には，互にあまり差 が認められなかつた。このうち安静臥床例および普通
Fig. 5. Optical Densities Obtained with THB, ATHB, THA, THF and THE at $525 \mathrm{~m} \mu$

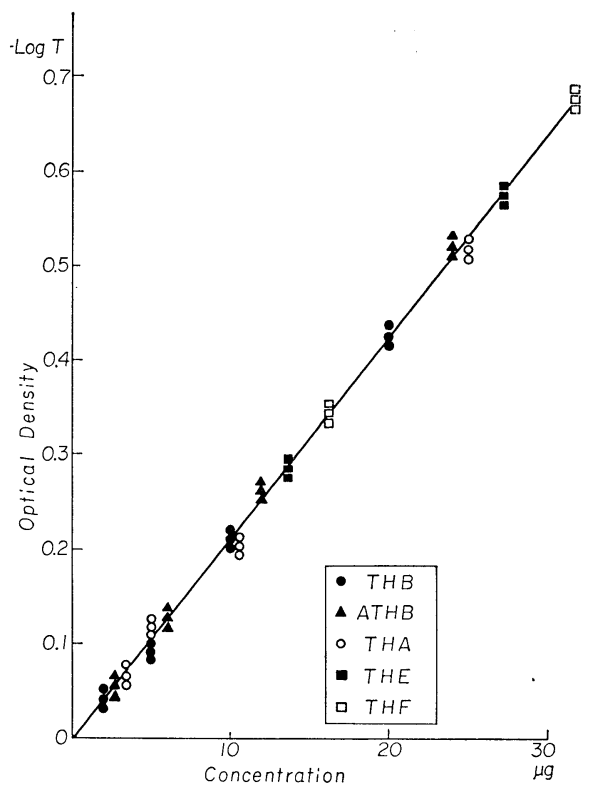

Fig. 7. Corticosterone Secretion Rate in Resting, Lightly Working and Heavily Working Normal Subjects

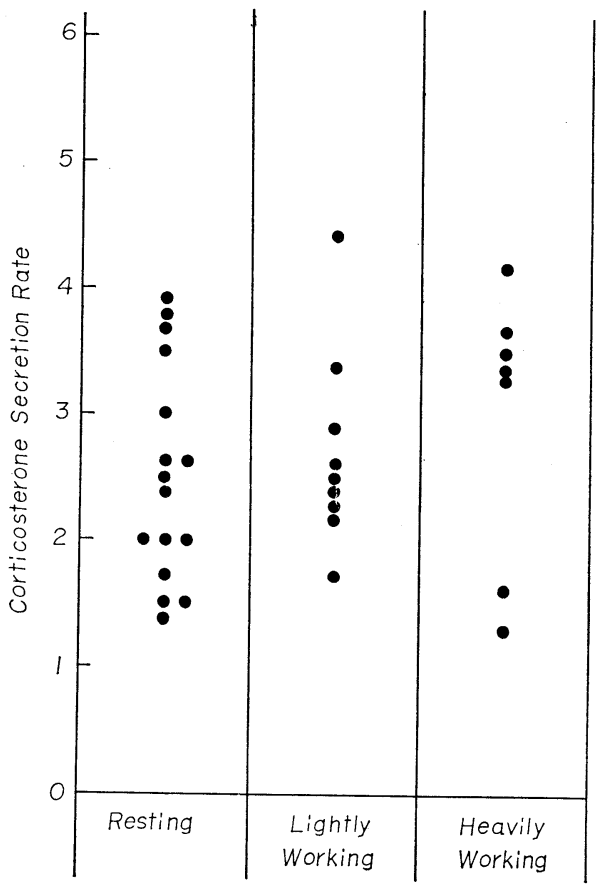


Table 1. Gorticosterone Secretion Rate in 25 Normal Subjects (16 Resting Subjects and 9 Light Workers)

\begin{tabular}{|c|c|c|c|c|c|c|c|c|c|c|c|}
\hline \multirow{3}{*}{ Subject } & \multirow{3}{*}{ Sex } & \multirow{3}{*}{ Age } & \multicolumn{9}{|c|}{ Corticosterone Secretion Rate } \\
\hline & & & \multicolumn{3}{|c|}{ Calculated from THB } & \multicolumn{3}{|c|}{ Calculated from АТНB } & \multicolumn{3}{|c|}{ Mean of Both Values } \\
\hline & & & $\mathrm{mg} / \mathrm{day}$ & $\begin{array}{l}\mu \mathrm{g} / \mathrm{kg} / \\
\text { day }\end{array}$ & $\begin{array}{l}\mathrm{mg} / \mathrm{m}^{2} / \\
\text { day }\end{array}$ & $\mathrm{mg} / \mathrm{day}$ & $\begin{array}{l}\mu \mathrm{g} / \mathrm{kg} / \\
\text { day }\end{array}$ & $\begin{array}{l}\mathrm{mg} / \mathrm{m}^{2} / \\
\text { day }\end{array}$ & $\mathrm{mg} /$ day & $\begin{array}{l}\mu \mathrm{g} / \mathrm{kg} / \\
\text { day }\end{array}$ & $\begin{array}{l}\mathrm{mg} / \mathrm{m}^{2} / \\
\text { day }\end{array}$ \\
\hline M. I . & $\mathrm{F}$ & 39 & 4.1 & 111 & 3.2 & 3.5 & 94.6 & 2.7 & 3.8 & 103 & 3.0 \\
\hline $\mathrm{Y} . \mathrm{T}$. & $\mathrm{F}$ & 42 & 3.4 & 72.1 & 2.5 & 2.6 & 55.6 & 1.9 & 3.0 & 63.9 & 2.2 \\
\hline $\mathrm{T} . \mathrm{T}$. & $\mathrm{F}$ & 20 & 3.2 & 55.6 & 2.0 & 3.8 & 66.1 & 2.4 & 3.5 & 60.9 & 2.2 \\
\hline $\mathrm{K} . \mathrm{O}$. & $\mathrm{F}$ & 25 & 2.0 & 36.1 & 1.3 & 2.0 & 35.4 & 1.3 & 2.0 & 35.8 & 1.3 \\
\hline $\mathrm{K} . \mathrm{K}$. & $\mathrm{F}$ & 60 & 1.5 & 28.3 & 1.0 & 1.5 & 28.3 & 1.0 & 1.5 & 28.3 & 1.0 \\
\hline T.H. & $\mathrm{F}$ & 23 & 1.5 & 26.3 & 1.0 & 1.5 & 26.3 & 1.0 & 1.5 & 26.3 & 1.0 \\
\hline M.K. & M & 21 & 4.5 & 73.8 & 2.7 & 2.9 & 47.5 & 1.7 & 3.7 & 60.7 & 2.2 \\
\hline M. T. & M & 21 & 3.9 & 75.0 & 2.5 & & & & 3.9 & 75.0 & 2.5 \\
\hline $\mathrm{T} . \mathrm{H}$ & $\mathbf{M}$ & 20 & 3.2 & 58.5 & 2.0 & 1.7 & 31.3 & 1.1 & 2.5 & 44.9 & 1.6 \\
\hline S.O. & $\mathbf{M}$ & 33 & 3.1 & 46.3 & 1.8 & 1.7 & 25.4 & 1.0 & 2.4 & 35.9 & 1.4 \\
\hline $\mathrm{K} . \mathrm{T}$. & $\mathbf{M}$ & 16 & 2.9 & 80.5 & 2.3 & 2.3 & 65.0 & 1.9 & 2.6 & 72.8 & 2.1 \\
\hline A.S. & $\mathbf{M}$ & 25 & 2.5 & 47.1 & 1.5 & 2.6 & 49.0 & 1.6 & 2.6 & 48.1 & 1.6 \\
\hline T.K. & $\mathbf{M}$ & 13 & 2.3 & 46.8 & 1.5 & 1.7 & 34.9 & 1.1 & 2.0 & 40.9 & 1.3 \\
\hline N.T. & $\mathbf{M}$ & 49 & 2.0 & 34.6 & 1.3 & & & & 2.0 & 34.6 & 1.3 \\
\hline S. I . & $\mathbf{M}$ & 61 & 1.6 & 28.8 & 1.0 & 1.8 & 31.9 & 1.1 & 1.7 & 30.4 & 1.0 \\
\hline T. Y . & $\mathbf{M}$ & 35 & & & & 1.4 & 21.5 & 0.8 & 1.4 & 21.5 & 0.8 \\
\hline $\mathrm{K} . \mathrm{O}$ & $\mathbf{M}$ & 31 & 4.0 & 59.2 & 2.3 & 4.6 & 67.0 & 2.6 & 4.3 & 64.2 & 2.5 \\
\hline S.H. & $\mathbf{M}$ & 46 & 3.4 & 66.0 & 2.2 & 3.4 & 66.0 & 2.2 & 3.4 & 66.0 & 2.2 \\
\hline I. S . & $\mathbf{M}$ & 46 & 3.2 & 42.8 & 1.7 & 2.6 & 34.6 & 1.4 & 2.9 & 39.2 & 1.6 \\
\hline T.S. & $\mathbf{M}$ & 48 & 2.6 & 40.4 & 1.5 & 2.6 & 40.4 & 1.5 & 2.6 & 40.4 & 1.5 \\
\hline K. G. & $\mathbf{M}$ & 45 & 2.5 & 41.0 & 1.6 & 2.3 & 37.0 & 1.5 & 2.4 & 38.8 & 1.6 \\
\hline S.M. & $\mathbf{M}$ & 41 & 2.5 & 47.1 & 1.6 & & & & 2.5 & 47.1 & 1.6 \\
\hline M.T. & $\mathbf{M}$ & 36 & 2.2 & 37.4 & 1.3 & 2.3 & 39.5 & 1.4 & 2.3 & 39.4 & 1.4 \\
\hline K. S . & $\mathbf{M}$ & 45 & 2.2 & 40.2 & 1.5 & 2.2 & 40.2 & 1.5 & 2.2 & 40.0 & 1.5 \\
\hline M.H. & $\mathbf{M}$ & 46 & 1.7 & 34.8 & 1.1 & 1.7 & 34.8 & 1.1 & 1.7 & 34.8 & 1.1 \\
\hline \multicolumn{3}{|c|}{ Mean } & 2.8 & 51.2 & 1.8 & 2.4 & 44.2 & 1.5 & 2.6 & 47.7 & 1.7 \\
\hline \multicolumn{3}{|c|}{ S.D. } & 0.8 & 19.8 & 0.6 & 0.8 & 17.9 & 0.5 & 0.8 & 18.9 & 0.6 \\
\hline
\end{tabular}

Table 2. Normal Values of Corticosterone Secretion Rate Reported in Literature (Calculated from the Specific Activity of the Urinary Metabolites)

\begin{tabular}{|c|c|c|c|c|c|c|}
\hline Authors & No. of Cases & $\begin{array}{c}\text { Corticosterone } \\
\text { Secretion Rate } \\
\text { mg/day }\end{array}$ & Isotope & Used & Urine & $\begin{array}{l}\text { Collection } \\
\text { hrs }\end{array}$ \\
\hline Peterson et $a l^{6}$ ) & 11 & 2.3 & ${ }^{14} \mathrm{C}$, & ${ }^{3} \mathrm{H}$ & & 24 \\
\hline Biglieri et $\mathrm{al}^{12}$ ) & 17 & 2.7 & ${ }^{14} \mathrm{C}$ & & & 24 \\
\hline Straeten et $\mathrm{al}^{10}$ ) & 14 & 3.4 & ${ }^{14} \mathrm{C}$ & & & 48 \\
\hline Karl et $\mathrm{al}^{13}$ ) & 12 & 3.3 & ${ }^{14} \mathrm{C}$ & & & 48 \\
\hline Kono et $\mathrm{al}^{14}$ ) & & $2.3 \sim 4.2$ & ${ }^{14} \mathrm{C}$, & ${ }^{3} \mathrm{H}$ & & 24 \\
\hline Ibayashi et $\mathrm{al}^{15}$ ) & 4 & 3.1 & $14 \mathrm{C}$ & ${ }^{3} \mathrm{H}$ & & 24 \\
\hline Present work & 25 & 2.6 & ${ }^{3} \mathrm{H}$ & & & 24 \\
\hline
\end{tabular}


Table 3. Serum Potassium Concentration, $\mathrm{C}_{\mathrm{K}}(\mathrm{Na}$ thiosulf.)*, Aldosterone Secretion Rate and Corticosterone Secretion Rate in 5 Patients with Primary Aldosteronism

\begin{tabular}{c|c|c|c|c}
\hline Patient & $\begin{array}{l}\text { Serum Potassium } \\
\text { Concentration }\end{array}$ & $\mathrm{C}_{\mathbf{K}}$ (Na thiosulf.) & $\begin{array}{l}\text { Corticosterone } \\
\text { Secretion Rate }\end{array}$ & $\begin{array}{c}\text { Aldosterone } \\
\text { Secretion Rate }\end{array}$ \\
\hline H.M. & $1.8 \mathrm{mEq} / \mathrm{L}$ & $57.4 \mathrm{ml} / \mathrm{min}$ & $5.6 \mathrm{mg} / \mathrm{day}$ & $415 \mu \mathrm{g} / \mathrm{day}$ \\
R.S. & 2.0 & 65.6 & 4.4 & 346 \\
G.O. & 1.9 & 47.7 & 3.6 & 1180 \\
S.O. & 2.9 & 37.3 & 2.2 & 694 \\
T.S. & 2.9 & 36.2 & 2.2 & 157 \\
\hline
\end{tabular}

* Potassium clearance measured after sodium thiosulfate loading ${ }^{42}$ )

Fig. 8. Correlation Between Corticosterone Secretion Rate and Body Weight

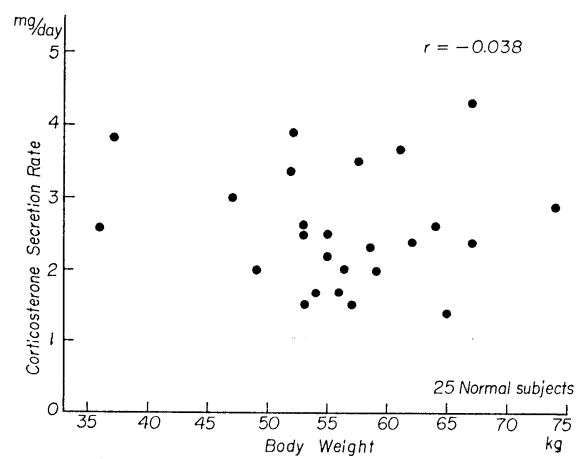

Fig. 9. Correlation Between Corticosterone Secretion Rate and Body Surface

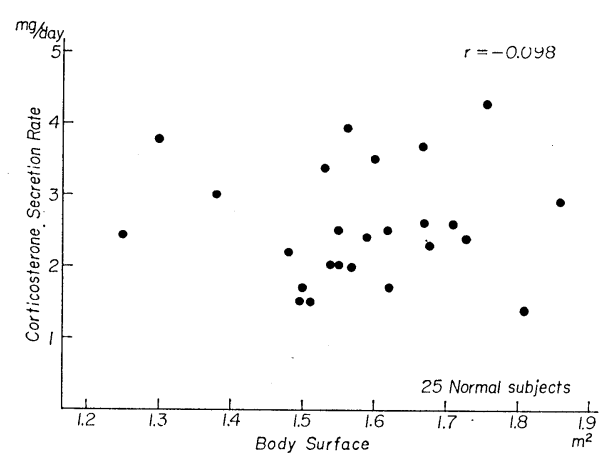

Fig. 10. Response of Corticosterone Secretion Rate to AGTH Stimulation

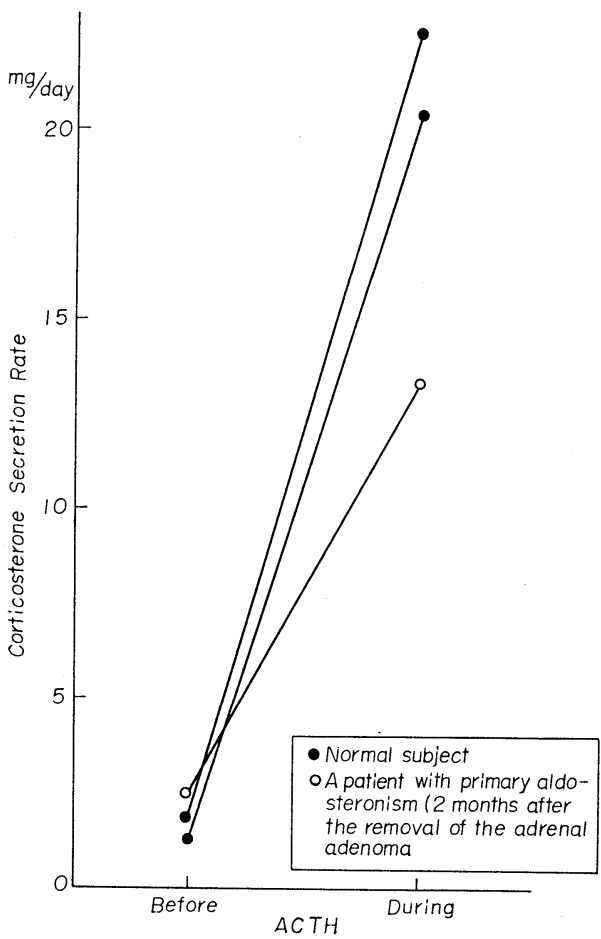

労働例を合わせた25例の平均值は，2.6mg $\pm 0.8 \mathrm{mg} / \mathrm{day}$ であり，本邦健常者における24時間 corticosterone 分泌量は，との程度のものと考えられる。(Table 1).

\section{4) Corticosterone 分泌量と体格との関係}

上述した健常者25例における corticosterone 分泌量と体重あるいは体表面積との関係を Fig. 8 および Fig. 9 に示した. corticosterone 分泌量と体重との相関係数は一0.038であり，体表面積とのそれは一0.098 であつた。すなわちいずれの場合にも全く相関は認められなかつた。

5) ACTH 投与時の corticosterone 分泌量 
highly purified ACTH 120単位 1 回筋注後 24 時 間の corticosterone 分泌量を, 健常者 2 例, 原発 性 aldosterone 症（左側副㹂を腺腫と共に摘出 2 ケ 月後）1例において測定した。 その結果，前者では 12倍以上の増加を, 後者でも 6 倍の増加反応を示す ことが認められた(Fig. 10).

6）各種高血圧症における corticosterone 分泌量 良性本態性高血圧症および腎血管性高血圧症にお ける corticosterone 分泌量は, 健常者のそれとの 間に殆んど差を示さなかつた。

原発性 aldosterone 症における corticosterone分 泌量は，3例では正常範囲に止まつたが，2例では 高值を示した(Fig. 11).

\section{考按}

\section{1) 測定法の検討}

isotope dilution method による各種副腎皮質ス テロイド分泌量の測定は，いくつかの仮定に基づい ているが ${ }^{9}$ ，実際に得られた值が分泌量を正確に反 映しているかどうかを check するのは困難なとと が多い．ただ当該ステロイドの数種の代謝産物より 分泌量を測定し，それらが互に完全に一致していれ ばその值は信頼し得るということが出来る。しかし corticosterone：分泌量に関してての点を詳細に検討 した報告は少ない。

Vermeulen 等(10)は, 2 種の paper chromatography により THB および ATHB を分離し corticosterone 分泌量を計算したが，両者の間にかなりの差を認めている．彼等は双方の比活性度が $20 \%$ 以の 差を示した場合には，更に他の paper chromatography を追加して，より純粋に精製しようと試みた。

私は silica gel column chromatography を前もつて行ない, その後に Vermeulen 等と同様に toluenepropylene glycol system および cyclohexane-benzene-methanol-water $(2: 2: 2: 1)$ の 種の paper chromatography により THB および ATHB を分離し，それらの比活性度より分泌量を算出したが， THB の比活性度の方が，ATHB のそれより大部分の例で若干ではあるが低值を示した。

この様に両代謝産物の比活性度が必ずしも一致しないのは，一般には blue tetrazolium で発色する不純 物が混入するためであろうと解されている。井林等 ${ }^{11} も$ 私と同様の結果を認め，おそらく THB fractionに tetrahydro-11-desoxycortisol (THS) が混入し，その分離が甚だ困難なためであろうと述べている.

しかしながら， 3 種以上の paper chromatography により更に精製しても，両者の比活性度が20\%以上 の差を示す場合があつたという Vermeulen 等 ${ }^{10}$ の報告から推定される如く，代謝産物の種類により，その代 謝あるいは排泄速度等に相違があることも考慮されねばならないであろう。

私の実験成績においても，THB および ATHB の比活性度に差がみられはしたが，しかしその差はそう 大きいものではなかつた。したがつて両者の相加平均より求めた分泌量は，ほぼ妥当な值を示しているもの と考えられる。

2) 健常者の corticosterone 分泌量
Fig. 11. Corticosterone Secretion Rate in Benign Essential Hypertension, Renovascular Hypertension and Primary

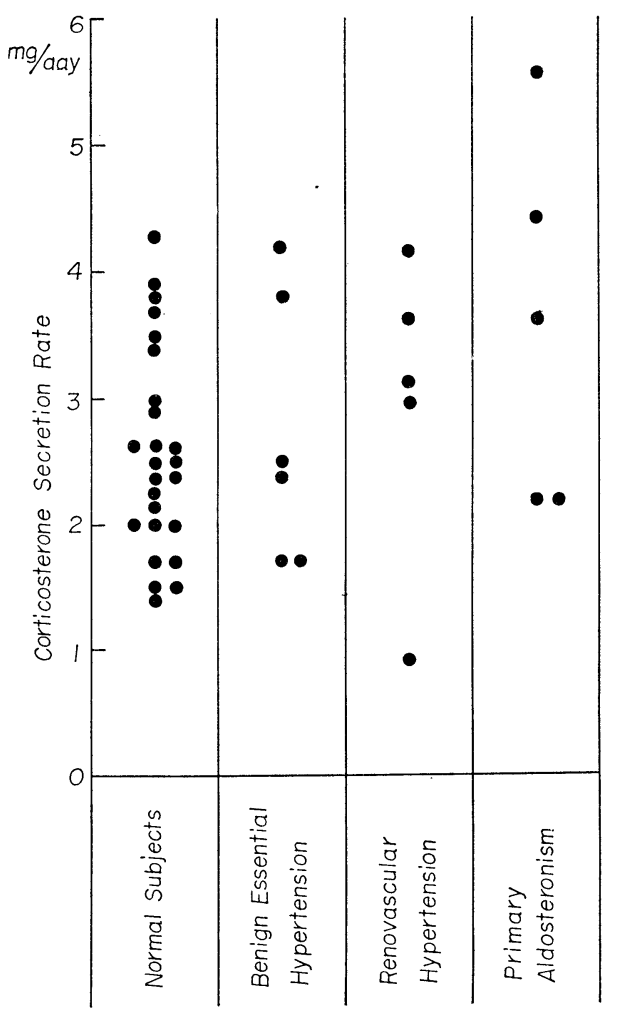


Table 2 に私の成績と共に本邦および諸外国における報告值を示したが，乙れら報告値の間には大きい差 は認められない．乙の点 cortisol 分泌量が本邦人において低值を示し，欧米人における值との間にかなりの ひらきがあるという成績とは異なるところである。すなわち cortisol 分泌量や尿中 17-OHCS 排泄量は, 体重あるいは体表面積と正の相関を有することが知られ，本邦人は欧米人より一般に体格が少さいため， 本邦人においては欧米人より低值を示すものと考朰れれてるる ${ }^{16}$.

Dohan 等 ${ }^{17)}$ は尿中 corticosterone 代謝産物を測定した結果，乙れが cortisol 代謝産物と同様に，体表面 積との間に有意の相関を示すととを梕めている。しかし私が corticosterone 分泌量を測定したところでは, 体重あるいは体表面積のいずれとも相関は認められなかつた。 てのような私の成績からすれば，体格のより 大きい欧米人について報告されている值と, 体格のより小さい本邦人について得られている值とが大差を示 さないのは当然のととと考えられる。私の成績と同様に，Karl 等 ${ }^{18}$ は健常者および単純性肥胖症の患者につ いて検討し， corticosterone 分泌量は体格と相関しないという結果を得ている.

\section{3）労働負荷による corticosterone 分泌量}

労働負荷により副腎皮質ホルモン，特に cortisol や corticosterone の分泌がどのように変動するかは極 めて興味あるところであるが， isotope dilution method により直接その変動を検索した報告はみられない 様である.

たとえば Thorn 等 ${ }^{19}$ は，ヒトに長時間の running を負荷して流血中の好酸球数および尿中 17-OHCS 排 泄量等の変動を検討している。それによると，好酸球数は running 直後に74\%減少したが，尿中17-OHCS 排泄量は running 中および running 直後にも変動しなかつたという. 従つてての場合の好酸球数の減少 が，副腎からのステロイド分泌増加によつたとは考えにくいと述べている. Hill 等 ${ }^{20}$ は, ボートレース選手 について，競技前，中，後の尿中 17-OHCS 排泄量を調べた結果，レース中から終了後数時間までの排泄 量は，レースの行なわれなかつた日の同一時刻内における排泄量よりは増加していたが，24時間排泄量とし ては有意の変動を示さなかつたと報告している.

Staehelin 等 ${ }^{21}$ が， bicycle ergometer を使用して 2 時間にわたり運動負荷を行なつた結果では, 血中 17OHCS濃度は負荷開始後30分迄は上昇を示したが，その後は負荷を持続しているにもかかわらず，逆に運動 負荷前よりも低下して来たという。このことから彼等は, 血中皮質ステロイド濃度は運動負荷により副腎皮 質が刺激されステロイド分泌が増大するために一時上昇するが，その後体内におけるホルモンの利用が分泌 増加を凌駕するに至るため, 低下をきたすものと推定している. Cornil 等 ${ }^{22}$ は, 同様に bicycle ergometer により20分間にわたり激しい運動を負荷した場合に, 血中 17-OHCS 濃度および血中 corticosterone 濃度 が，いずれも負荷により上昇するととなく，むしろ漸次低下し，ての傾向は負荷終了後50分にわたり持続す るととを認めた，ての結果から彼等は，運動負荷により副腎皮質が刺激されるかどうかは結論されないが， 少なくとも体内におけるこれらホルモンの利用が高まり，その distribution space が増大することが血中濃 度の低下をきたす大きな因子となつているであろうと述べている。

以上の様にてれらの報告は, いずれもストレス時の副腎皮質ホルモン分泌の変動に関する間接的な検討に すぎない.これに対し isotope dilution method による分泌量の測定は，乙の問題を解明する直接的な有 力な方法となると考えられる。ただ尿中代謝産物の比活性度より副腎皮質ホルモン分泌量を測定する場合に は，投与した isotope の尿中への排泄に比較的長時間を要するため，短時間の運動負荷による急性の変動を 追求するのには不適当である.

そこで私は, 短時間の激しい運動負荷の代りに, 高温多湿下で 8 時間というかなりの長時間にわたる重労 働に携わつた 7 例について，労働開始直前に isotope を投与して，その後24時間の corticosterone 分泌量を 測定した. その結果では, 安静臥床例および普通労働例における場合と余り差のない值を得たに止まつた。 後述する如く私の実験では, Peterson の報告と同様に, corticosterone 分泌は ACTH に極めて敏感に反応 するととが認められた，従つて corticosterone 分泌は cortisol 分泌と同様に下垂体依存性であると考兄ら れる.それでもなお，乙れら重労働者において corticosterone 分泌量の増加が認められなかつたのである 
から，日常継続反復されている様な労働では，たとえそれがかなり激しいものであつても，それにより副腎 皮質か溂激される程のととはないものと考光られる。乙の点に関して教室の勝島 ${ }^{23}$ は, 私の実験と同じ条件 下で cortisol 分泌量を測定したところ, cortisol 分泌量も殆んど増加しないという同じ様な結果を得ている.

\section{4) ACTH 投与による corticosterone 分泌量}

Peterson ${ }^{\left.6)^{9}{ }^{24}\right)}$ は ACTH を投与すると, cortisol 分泌量は勿論ながら corticosterone 分泌量も著增するて とを認め, corticosterone 分泌は ACTH に支配されることを明かにした。 私は highly purified AGTH (第一製薬) 120 単位を 1 回筋注したのみで，corticosterone 分泌量は約12倍にも著増するてとを認めた。

ての観点からすれば, ACTH 分泌の少ない panhypopituitarism 等では, corticosterone 分泌量の低下 が推定される．実際私が，1例ではあるが，craniopharyngioma による panhypopituitarism の患者につ き corticosterone 分泌量を測定したととろ， $0.3 \mathrm{mg} / \mathrm{day}$ という極めて低い值を示すととが認められた。た だ Vermeulen 等 ${ }^{10}$ は, panhypopituitarism の1例で， cortisol 分泌量は非常に低い值を示したのにくらべ て corticosterone 分泌量はそれほど低い值を示していなかつたので, corticosterone 分泌は aldosterone 分 泌と同様に，あまり ACTH の支配をうけず，また zona glomerulosa から分泌されるのであろうと述べ ている。もつともとの例の corticosterone 分泌量は $0.5 \mathrm{mg} /$ day であつたということであるから, 彼等の正 常值 $1.6 〜 5.5 \mathrm{mg} / \mathrm{day}$ にくらべれば，低值を示したと考えるのが妥当と思われる.

\section{5）本能性高血圧症における corticosterone 分泌量}

本態性高血圧症について corticosterone 分泌量を検討した報告は少ない，1963年 Vermeulen 等 ${ }^{25}$ は，良 性本態性高血圧症における corticosterone 分泌量が正常範囲にあつたととを認め，本態性高血圧症の生成 機転に corticosterone が何等かの関与を有しているとは考えられないと述へている．また Dohan 等 ${ }^{17} も$ 高 血圧患者における corticosterone 代謝産物の沓中排泄量は, 正常血圧者と同程度であつたと報告している. 他方松岡等 ${ }^{26}$ は，本態性高血圧症における血中 corticosterone 濃度は著明に上昇しており，治療により血 圧が正常化すると血中 corticosterone 濃度も正常域にもどることを認めたという。このてとから彼等は，血 圧の変動そのものと corticosterone 血中濃度とが密接な関連を有するものと考えている.

私の実験成績では，Vermeulen 等の成績と同様に良性本馝性高血圧症の corticosterone 分泌量は，正常血 圧者のそれと殆んぞ差がなく，少なくとも本態性高血圧症と corticosterone 分泌量との間に密接な関連が存 在するものとは思われなかつた。

\section{6）腎血管性高血圧症における corticosterone 分泌量}

renin-angiotensin system は aldosterone 分泌を增加させるととが知られている.ただ cortisolや corticosterone に対しても明かな刺激効果を示すか否かについては，必ずしも見解が一致していない，例えば Biron 等 ${ }^{27}$ は, angiotensin II をと卜亿静注して尿中 aldosterone 排泄が著増し, 同時に cortisol 排泄も 軽度ながら増加するととを認めた。ささらに Slater 等 ${ }^{28}$ は，下垂体および腎摘除をした犬に angiotensin II を投与した実験において，aldosterone， corticosterone および cortisol の分泌は殆んど同程度に刺激され， dose response をみても， aldosterone 分泌增加をもたらす程の量なら，たとえ極めて微量であつても， cortisol および corticosterone 分泌をも増加させると述へている．また彼等 ${ }^{30}$ は，下垂体摘除犬において潟 血を行なつた場合や，あるいは下垂体摘除犬において腎動脈分㞳部より上部の大動脈または腎動脈を狭窄し た場合, 副腎静脈血中への cortisol および corticosterone の分泌が, aldosterone と匹敵する程の増加を示 したと述べている.

ところが，Mulrow 等 ${ }^{29}$ は，下垂体摘除犬で腎動脈より上部の大動脈を狭窄した場合, 副腎静脈血中 aldosterone 濃度は著明に上昇したが， corticosterone や17-OHCS の濃度には認むべき変動がなかつたと述べ ている。 また Davis 等 ${ }^{31} も$ も，下垂体を摘除しない犬で，腧部下大静脈を狭窄した場合に同様の成績を認めて いる。ささらに最近 Fraser 等 ${ }^{32}$ は，ヒトに angiotensin II を静注したととろ，血中 aldosterone 濃度は上 昇したが， cortisol および corticosterone の濃度は上昇しなかつたと述べている.

私が対象とした腎血管性高血圧症 5 例は，いずれも腎動脈撮影或は手術により狭窄の存在が確められ，ま 
た教室の吉永や前橋等により血中 renin 活性が $2.2 \sim 5.4 \mu \mathrm{g} / \mathrm{L}$ of plasma（正常範囲 $0 \sim 2 \mu \mathrm{g} / \mathrm{L}$ of plasma) と明かに上昇しているととが認められ，さらに教室の福地や後藤により aldosterone 分泌量も 192〜1126 $\mu \mathrm{g} / \mathrm{day}$ (正常範囲 83〜138 $\mu \mathrm{g} / \mathrm{day}$ ) と增加しているととが認められた例である. しかしながら corticosterone 分泌量は全例正常範囲に止まつた。

上述した样に Slater 等 ${ }^{30}$ は, 下垂体摘除犬における実験から, renin-angiotensin system そより cortisol や corticosterone の分泌が増大するととを認め, Davis 等の実験で cortisol や corticosterone の分泌が増 加しなかつたのは, feed-back 機序により下垂体からの ACTH 分泌が抑制され, cortisol や corticosterone の分泌は aldosterone の分必とはちがつて ACTH 依存性であるので，みかけ上明かな変動を示さなかつ たのであろうと推測している，さらに彼等は，nephrotic syndrome や肝硬変症で浮腫が存在している様な 場合には，もし下垂体がなければ feed-back 機序が働かないので, cortisol や corticosterone も aldosterone 分泌增大に敵する程の増加を示すのではないかと推測している．私の成績や Fraser の実験で aldosterone の増加が認められたのに corticosterone 分泌増加が認められなかつたのは, Slater 等の推測した様な機序 が，ヒトにおいても働いていたためかも知れない，ヒトにおける renin-angiotensin に対する副腎皮質ホル モン, 特に glucocorticoids の反応態度については, 下垂体との関連においてさらに深い検索を進める必要 があると思われる。

\section{7）原発性 aldosterone 症における corticosterone 分泌量}

原発性 aldosterone 症において, corticosterone 代謝産物の尿中排泄量が増加していたという報告 ${ }^{33}$ 34)35) $^{335}$ や，また副腎腺腫組織中における corticosterone 含有量が増加していたという報告 ${ }^{1236363738}{ }^{38}$ がみられる. 特 に Biglieri 等 ${ }^{12}$ は, 7 例の副腎腺腫に上る原発性 aldosterone 症の患者において, 腫煌組織中の corticosterone 濃度は全例増加していたと述べている。またてれらの例の corticosterone 分泌量は 3 例で高値を，4 例で正常値を示したが，腫煌組織中の含量が高かつたもの程，分泌量も高值を示したと報告している．

1960年 Ross ${ }^{39}$ は，彼自身や諸疾患患者を対象として，尿中カリウムの排泄量は aldosterone 単独よりも corticosterone を一緒に投与した場合に一層増加するととを観察した。乙の成績から彼等は，原発性 aldosterone 症における低カリウム血症には corticosterone 分泌増加が大きく関与していると考元た。しかし最 近になつてての考光を訂正 ${ }^{40} し$ し 本症の低カリウム血症は, corticosterone の関与によるのではなく, aldostrone の主として extra-renal の作用により糞便へのカリウム排泄増加がおてるてとによるものであろうと 推測している. 本邦においては, 大林等 ${ }^{41}$ は原発性 aldosterone 症の corticosterone 分泌量は, 6 例中 1 例のみが高値を示し，他は正常範囲にあつたと報告している.

以上の様に原発性 aldosterone 症における corticosterone の関与については，必ずしも一致した見解が とられていない.

Table 3 は私の測定した原発性 aldosterone 症 5 例における corticosterone 分泌量を, 他の検查成績と 共に示したものである。乙れによれば, corticosterone 分泌量は 2 例で高值を示し，他の 3 例は正常範囲に 止まり，一定の傾向は認められなかつた。しかし血清カリウムが低い例程，またチオ硫酸ソーダ負荷カリウ ムクリアランス值 ${ }^{42}$ が増大している例程，高値を示す傾向が認められた。 てのととは corticosterone が，生 体内のカリウムの変動に対して何等かの役割を演じている可能性を示唆するものと考えられる.

結論

1,2- ${ }^{3} \mathrm{H}$-corticosterone 静注後の 24 時間尿について， corticosterone 主要代謝産物である THB および ATHB の比活性度より24時間 corticosterone 分泌量を測定した。

1) Corticosterone 代謝産物である THB, ATHB および THA は, いずれも blue tetrazolium 反応で 同程度の呈色度を示した. Cortisol 代謝産物である THF および THE も同様であつた.

2) THB および ATHB から計算した corticosterone 分泌量は，前者がやや高值を示したが，その差は 僅少であつたので, 両者の相加平均をもつて分泌量を算出した. その結果, 健常者25例における corticoste- 
rone 分泌量は, 平均 $2.6 \mathrm{mg} \pm 0.8 \mathrm{mg} / \mathrm{day}(1.4 \sim 4.3 \mathrm{mg} / \mathrm{day})$ であつた.

3）重労働者（高温多湿下）の corticosterone 分泌量は，安静時および普通労働時のそれとの間に有意の 差を示さなかつた。

4) corticosterone 分泌量は, 体重あるいは体表面積と何等の相関をも示さなかつた.

5) corticosterone 分泌量は AGTH 投与により著增した。 また panhypopituitarism の1例では極めて 低い值を示した。

6）良性本態性高血圧症 6 例および腎血管性高血圧症 5 例における corticosterone 分泌量は，ほほ正常範 囲に止まつた。

7）原発性 aldosterone 症 5 例における corticosterone 分泌量は, 2 例で高值を示し, 他の 3 例では正常 範囲に止まつた。うち高值を示した 2 例における血清カリウムはより低值を示し, かつチオ硫酸ソーダ負荷 カリウムクリアランス値はより増大していた。

稿を終るにあたり, 終始御㤅篤なる御指導と御校閲を睗わつた恩師鳥飼龍生教授, 並びに終始御指導と御 鞭擭を睗わつた三浦清, 勝島一郎, 福地総逸博士に, 衰心より謝意を表します.

本論文要旨は, 第十三回日本内分泌学会東部部会総会に扔いて発表した。

\section{文献}

1) FREMERY, P.D., E. LAQUEUR, T. REICHSTEIN, R.W. SPANHOFF and I.E. UYLDERT : Nature, $139: 26$, (1937). 2) REICHSTEIN, T. : Helv. Chim. Acta, $20: 953$, (1937). 3) MASON, H.L., W.M. HOEHN, B.F. MCKENZIE and E.C. KENDALL : J. Biol. Chem., $120: 719$, (1937). 4) BURTON, R.B., A. ZAFFARONI and E.H. KEUTMANN : J. Biol. Chem., $188: 763$, (1951). 5) ZAFFARONI, A. and R.B. BURTON : J. Biol. Chem., $193: 749$, (1951). $\quad$ 6) PETERSON, R.E. and C.E. PIERCE : J. Clin. Invest., $39: 741$, (1960).

7) NOWACZYNSKI, W., M. GOLDNER and J. GENEST : J. Lab. Clin. Med., $45: 818$, (1955).

8) BRAY, G.A. : Anal. Biochem., $1: 279$, (1960).

9) PETERSON, R.E. : Recent Prog. Hormone Res., 15 : 231, (1959).

STRAETEN, M.V.D., A. VERMEULEN and N. ORIE : Acta Endocr. (Kbh), $43: 430$, (1963). 11) 佐々木爾, 勝島一郎, 大友利夫, 佐藤重行, 三浦 清: 第13回日本内分泌学会東部部会総会口演 (1965). BIGLIERI, E.G., S. HANE, P.E. SLATON, and P.H. FORSHAM : J. Clin. Invest., 42 : 516, (1963). 13) KARL, H.J. and L. RAITH : Klin. Wschr., 43 : 863, (1965).

14）河野剛, 吉見輝也, 守屋薰, 松 田孝之, 川瀬満雄，山田重樹，大林誠一，近藤俊文：綜合臨床，12:688, (1963)。115）井林博：代謝, $1: 259,(1964)$.16) 三浦清：第13回日本内分泌学会東部部会総会シンポジゥム,(1965)。ホと臨牀, 14 : 205, (1966). 17) DOHAN, F.C., H. BULASCHENKO and E.M. RICHARDSON : J. Clin. Endocr., 22 : 916, (1962). 18) KARL, H.J. and L. RAITH : Klin. Wschr., $43: 867$, (1965). 19) THORN, G.W., D. JENKINS and J.C. LAIDLAW : Recent Prog. Hormone Res., 8 : 171, (1953). 20) HILL, S.R., F.G. GOETZ, H.M. FOX, B.J. MURAWSKI, L.J. KRAKAUER, R.W. REIFENSTEIN, S.J. GRAY, W.J. REDDY, S.E. HEDBERG, J.R. ST. MARC and G.W. THORN : Arch. Intern. Med., $97: 269$, (1956). 21) STAEHELIN, D., A. LABHART, R. FROESGH and H.R. K ÄGI : Acta Endocr. (Kbh), $18: 521,(1955) . \quad 22)$ CORNIL. A., A.D. COSTER, G. COPINSCHI and J.R.M. FRANCKSON : Acta Endocr. (Kbh), $48: 163$, (1965). 23) 勝島一郎 : 第13回日本内分 泌学会東部部会総会口演,(1965). 日内分泌誌投稿中. 24) PETERSON, R.E. : J. Clin. Endocr., 17 : 1150, (1957). 25) VERMEULEN, A. and M.V.D. STRAETEN : J. Clin. Endocr., 23 : 574, (1963). 26）松岡松三，竹本吉夫，会田正道，佐々木英夫，渡辺勝已，青木和男，金子和男，草間光俊，鈴木芳 郎, 近藤隆, 竹内昭, 真山俊, 畠野尚弘：第62回日本内科学会口演, (1965). 27 BIRON, P., E. KOIW, W. NOWACZYNSKI, J. BROUILLET and J. GENEST : J. Clin. Invest., $40: 338$, (1961). 
28) SLATER, J.D.H., B.H. BARBOUR, H.H. HENDERSON, A.G.T. GASPER and F.G. BARTTER : J. Clin. Invest., $42: 1504,(1963)$.

29) MULROW, P.J. and W.F. GANONG : Aldosterone, 1st ed. (1964), 265, Blackwell Scientific Publications, Oxford, London.

30) SLATER, J.D.H., B.H. BARBOUR, H.H. HENDERSON, A.G.T. GASPER and F.C. BARTTER : Glin. Sci., 28 : 219 , (1965). $\quad 31$ ) DAVIS, J.O., G.G.J. GARPENTER, C.R. AYERS and R.C. BAHN : Amer. J. Physiol., 199 : 212, (1960). $\quad$ 32) FRASER, R., V.H.T. JAMES, J.J. BROWN, P. ISAAC, A.F. LEVER and J.I.S. ROBERTSON : Lancet, 2 (7420) : 989, (1965).

33) MADER, I.J. and L. T. ISERI : Amer. J. Med., $19: 976$, (1955). $\quad 34)$ SKANSE, B., F. MÖLLER, K. GYDELL, S. JOHANSSON and H.B. WULFF : Acta Med. Scand., 158 : 181, (1957).

35) PASQUALINI, J.R., P.M. JARVIS, M. LEGRAIN, G. LAFOSGADE and M.F. JAYLE : Ann. Endocr. (Paris), 25 : 433, (1964). $\quad 36)$ FUKUGHI, S. : Tohoku J. Exper. Med., 76 : 365, (1961).

37) GOLDSMITH, R.S., W. MERONEY and F.G. BARTTER : J. Glin. Endocr., 20 : 1168, (1960). 37) MIESCHER, V.P., O. GSELL, R. NISSEN, R. NEHER, F. GLOOR and L. SUTER : Schweiz. Med. Wschr., 90 : 181, (1960). $\quad 39)$ ROSS, E.J. : J. Clin. Endocr., $20: 229$, (1960). 40) ROSS, E.J. and P.E. HURST : Glin. Sci., 28 : 91, (1965).

41）大林誠一，吉見輝也，河野剛：第38回日本内分泌学会総会 口演 (1965)。 42）阿部末三郎：日腎誌，6:261，(1964). 